\title{
Evaluation of Some Physicochemical Parameters of Cevdet Dündar Pond (Yozgat/Turkey) Based on Bathymetric Map and Field Measurements
}

\author{
Şeyda ERDOĞAN ${ }^{1 *}$, Arda ÖZEN ${ }^{2}$, Şenol AKIN ${ }^{3}$, Semih EDİ̧s²
}

\begin{abstract}
Cevdet Dündar pond is located between the Fatih Nature Park and Yozgat Pine Grove National Park boundaries in Yozgat where semi-arid climate prevails with cold-rainy winters and arid-dry summers. The pond serves as a main water source for local communities. However, limnologic studies have not been conducted in the pond until today. The aim of this study is to create a bathymetric map of the pond in order to determine usable volume, depth change and to conduct first preliminary limnologic study in the pond to create the necessary sub-study for future sustainability studies. Moreover, some physicochemical parameters (water temperature $\left({ }^{\circ} \mathrm{C}\right.$ ), $\mathrm{pH}$, dissolved oxygen $(\mathrm{mg})$, saturated oxygen $(\%)$, conductivity $(\mu \mathrm{S} / \mathrm{cm})$, salinity $(\%)$ and total dissolved solid $\left(\mathrm{mg} \mathrm{L}^{-1}\right)$ ) were measured from the whole water column at $50 \mathrm{~cm}$ intervals for 11 months. Accordingly, a bathymetric map of the lake was created, total area and volume of the pond were calculated. According to results the maximum area of the pond was $29536.7 \mathrm{~m}^{2}$ and volume of the pond was $225209.59 \mathrm{~m}^{3}$. During the study period average dissolved oxygen and saturated oxygen were determined as $6.7 \mathrm{mg}$ and \% 72.4. While highest average water temperature was measured during the August (2018) with $17.7^{\circ} \mathrm{C}$, lowest temperature was recorded during March as $5.7{ }^{\circ} \mathrm{C}$. Thermal stratification was observed in summer months. The difference in water temperature between the epilimnion and hypolimnion was changed between $10-13{ }^{\circ} \mathrm{C}$. Anaerobic conditions were also measured in hypolimnion layer. Average of monthly $\mathrm{pH}$, conductivity, salinity and total dissolved solid were calculated as $7.7 \mathrm{mg} \mathrm{L}^{-1}, 176.7 \mu \mathrm{S} / \mathrm{cm}, 0.08$ ppm, 88.1 respectively.
\end{abstract}

Key words: Yozgat Pine Grove National Park, Cevdet Dündar Pond, Bathymetry, Lentic waters, Wetlands, Ecosystem

${ }^{1}$ Şeyda ERDOĞAN, (Orcid ID: 0000-0001-7729-7664), Yozgat Bozok University, Department of Biology, Yozgat, Turkey 2 Arda ÖZEN , (Orcid ID: 0000-0001-5315-8424), Semih EDİ̧, (Orcid ID: 0000-0003-4211-2476), Çankırı Karatekin University, Department of Forest Engineering, Çankırı, Turkey

${ }^{3}$ Şenol AKIN (Orcid ID: 0000-0002-3851-4360), Yozgat Bozok University, Department of Fisheries, Yozgat, Turkey *Sorumlu Yazar/Corresponding Author: Şeyda ERDOĞAN, e-mail: erdogan.seyda@gmail.com 


\section{INTRODUCTION}

Wetlands are essential resources for all living organisms and human. The amount of freshwater (3\%) that is essential for terrestrial life forms is limited, river and lake ecosystems constitute only $0.02 \%$ of the total freshwater on Earth. In addition, freshwater resources are available in polar regions and as groundwater, with percentages of $2.1 \%$ and $0.6 \%$ respectively. The remaining sea and oceanic saltwater constitute 97.2\% (Moss, 2010). Moreover, underground and aboveground freshwater amount vary regionally (Carpenter et al., 1992). According to the data of the United Nations Food and Agriculture Organization, the annual amount of water per capita is $24000 \mathrm{~m}^{3}$ year $^{-1}$ in America, $9300 \mathrm{~m}^{3}$ year $^{-1}$ in Europe, $5000 \mathrm{~m}^{3}$ year $^{-1}$ in Africa and $3400 \mathrm{~m}^{3}$ year $^{-1}$ in Asia (Vallée and Margat, 2003). Countries with per capita amount of water is less than $1000 \mathrm{~m}^{3}$ are classified as 'poor', this amount is around $1519 \mathrm{~m}^{3}$ for Turkey in 2010. As reported by Turkey Statistical Institute (TUIK), Turkey's population is projected to be 100 million in 2030. According to this estimate, the amount of water per capita in 2030 was calculated as $1120 \mathrm{~m}^{3}$ year $^{-1}$ (Republic of Turkey Ministry of Forestry and Water Affairs). Accordingly, Turkey may take place in 'water-poor' countries in the near future.

Dams and irrigation ponds are important because they provide water supply, flood protection, habitat for aquatic organisms and create recreation areas (Brainwood and Burgin, 2009; Takamura, 2012). There are more than 150000 dams on the earth for drinking, irrigation, industrial water supply, flood protection and electric power generation (Akarun, 1983). There is no doubt that water demand will continue to increase (Vörösmarty et al., 2000; Meerhoff et al., 2012). In the light of these data, it is necessary to protect and monitor the existing water resources in order to cope with the problems that may appear in the future. Moreover, to better understand ecosystem functioning bathymetric maps are essential for all kind of lentic water sources (Harper, 2015). Due to excessive erosion, a lot of sediment accumulates in dams and lakes every year and negatively affects the average life of lentic ecosystems (Rowan et al., 1995; Ziegler and Nisbet, 1995; Schleiss et al., 2016). That's why, it is necessary to monitor our lentic ecosystems and make hydrographic/bathymetric maps in every five years (Şapçılar and Fakıoglu, 2003). Although there are studies on bathymetry and physico-chemical parameters of ponds in Turkey (Tepe et al., 2005; Göncü et al., 2015; Mutlu and Paruğ, 2018; Mutlu and Güzel, 2019), the number of studies in this field is not sufficient and it is necessary to ensure the continuity of these studies.

The word bathymetry is a derivative of the Greek words bathus (deep) and metron (measure), meaning depth measurement. Bathymetry maps can be made by using conventional sounding methods or by using advanced acoustic sonar systems (Huertos and Smith, 2013). It is important to have up-todate bathymetric maps to ensure efficient use of ponds. Bathymetric mapping of small ponds is time consuming, costly and labor-intensive. Area, volume, volume changes and sediment accumulation of ponds can be calculated by using bathymetric maps (Hollister and Milstead, 2010). In addition, how much water is lost by evaporation and how much water comes from rainfall can be calculated (Escobar et al., 2009). Knowing the water volume of the pond is also important for the planning of the water budget. These data are important in the preparation of annual operating programs of ponds. Dry periods have caused serious water problems in the region and in the past.

Yozgat is in a region where semi-arid climate prevails with cold-rainy winters and arid-dry summers. Depending on climate change, dry periods are expected to be longer in the future (Jeppesen et al., 2009; Özen et al., 2010; Bucak et al., 2012). The pond is located between Yozgat Pine Grove National Park and Yozgat Fatih Natural Park, and it is the main water source for wildlife, which increases the importance of the pond. However, limnologic studies have not been conducted in 
the pond until today. The aim of this study is to create a bathymetric map of the pond to determine the actual usable volume, depth change and to create the necessary sub-study for future sustainability studies. We also aimed to conduct the first preliminary limnologic study in the pond.

\section{MATERIALS AND METHODS}

\section{Study Area}

Yozgat Pine Grove National Park and Fatih Nature Park located in the south of Yozgat province in Central Anatolia. Cevdet Dündar Pond located within the Fatih Nature Park boundaries and between two Park area. The pond was built as a drinking water source for Yozgat city in 1972-74. But is not currently used for this purpose. There are three creeks in the basin area of the pond. Katran and Divanl1 creeks are dried up, only Kavaklı creek has seasonal flow and they also have a small basin area. Seasonal weak water flow from creeks during rainy seasons, snow melt and ground water are main water sources of the pond. Today pond area serve as a recreational area and human effect on ecosystem is relatively highest around the pond. Plastic pollutants such as bottles, bags, straws regularly are observed around the pond shores. On the other hand, since basin area is under protection, basin originated pollution has very limited effect on pond ecosystem.

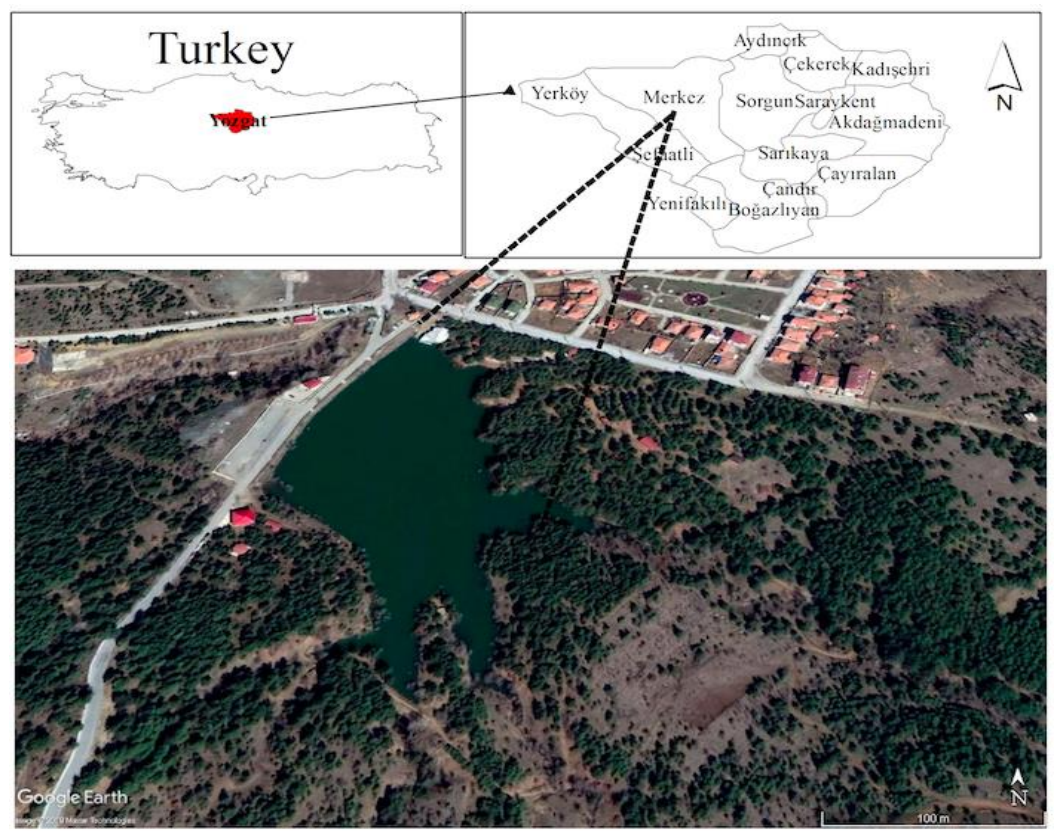

Figure 1. Location of Cevdet Dündar Pond in the Yozgat province of Turkey

Yozgat Pine Grove National Park is Turkey's first national park and established in 1958 and the park area is 264 hectares and composed of forest and shrub ecosystems. Park area provides suitable habitat for plant and animal species. Total 399 plant species were recorded in the park area belonging to 56 families and 70 of this species were endemic in the region. While black pine is the most common species oak, juniper and rosehip species are some of the plant species growing in the national park area. 9 bird, 4 mamalian and 3 reptilian species also recorded in the region (Ayten and Dede, 2007; Ersoy and Daşdemir, 2016; Environmental Status Report of Yozgat Pine Grove National Park, 2017).

Fatih Nature Park was established in 2013 and covers 242 ha area. 71 plant taxa belonging to 64 genera and 30 family recorded. Moreover 3 amphibians, 8 reptilians, 46 bird and 11 mammalian species observed in the park area. Recreational areas also placed in Fatih Nature Park and around the Cevdet Dündar Pond (Development Plan of Fatih Nature Park, 2018). 


\section{Field Measurements}

Cevdet Dündar Pond was sampled monthly for 13-month period, from August 2018 to August 2019. Since the pond was covered with ice, sampling could not be conducted in January and February. Water temperature $\left({ }^{\circ} \mathrm{C}\right), \mathrm{pH}$, dissolved oxygen $\left(\mathrm{mg} \mathrm{L}^{-1}\right)$ saturated oxygen $(\%)$, conductivity $(\mu \mathrm{S} / \mathrm{cm})$, salinity (\%) and total dissolved solid (TDS) $\left(\mathrm{mg} \mathrm{L}^{-1}\right)$, were measured monthly from the deepest point of the lake with multi-parameter probe (Hanna HI98194/20).

\section{Generation of Bathymetric Map}

In August 2018, bathymetric survey was conducted in the pond. A transect-based sampling method was used to determine the depth of the pond. Water depth of each sampling point was measured with a handheld sound meter (Plastimo Echoset). The coordinates for each sampling point were recorded using a GPS with $\pm 2 \mathrm{~m}$ accuracy. Distribution of sampling points were shown in Figure 2.

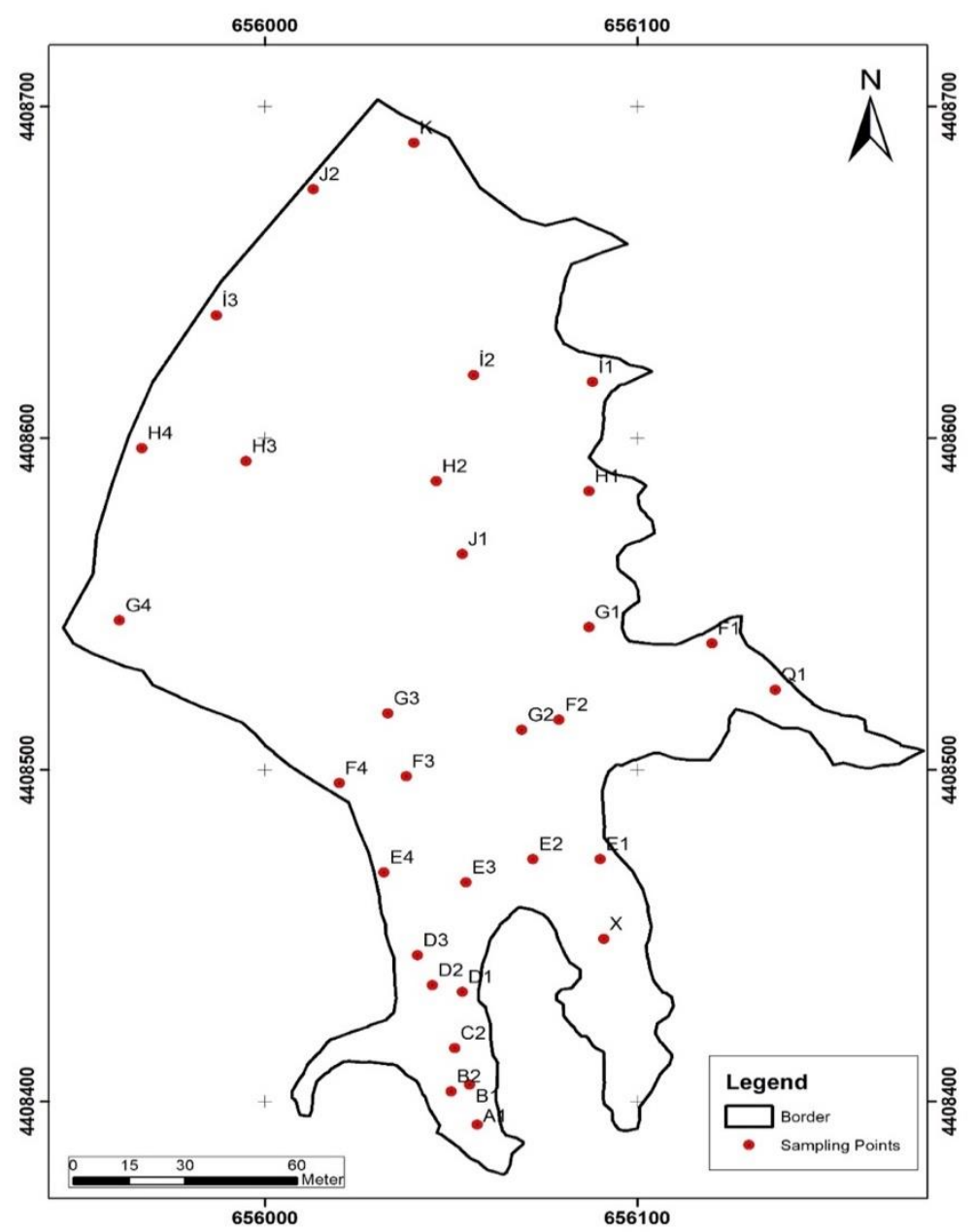

Figure 2. Sampling points for bathymetric map

An XYZ vectoral database containing coordinate and depth values of 32 points in 10 transects obtained from bathymetry survey in Microsoft Excel and these data were transferred to ARCGIS software. The bathymetry map was created by using ArcGIS 10.0 software (Figure 4).

Estimation of the depth of the whole pond set was performed by using this XYZ data in Geostatistics analysis methods in Geographical Information Systems (GIS). The pond depth data set was placed as a separate layer. In order to estimate the depth of the whole pond area, the statistical 
interpolation method Ordinary Kriging (OK) interpolation method and Spherical semi-variogram model were used. The depth of the pond was estimated by using 32 points measured in the field by this method.

Depth-dependent area volume values of pond were created by using storage capacity tool extension in ARCGIS software (Table 2).

\section{RESULTS AND DISCUSSION}

Monthly changes in the physiological parameters of Cevdet Dündar Pond between August 2018 and August 2019 were shown in Table 1. Physicochemical parameters of Cevdet Dündar Pond showed noticeable variations from the surface to the bottom in the time of the thermal stratification (TS). Thermal stratification started from $\sim 5$ meters in summer months and temperature difference between epilimnion and hypolimnion was varied from 10 to $13{ }^{\circ} \mathrm{C}$. The hypolimnion layer accounted for about $75 \%$ of the pond volume. In addition to the temperature, a significant DO concentration difference observed between epilimnion and hypolimnion layers. Since robust TS reduces DO diffusion from epilimnion to hypolimnion, anaerobic conditions were also measured in hypolimnetic area (Figure 3). The values of water temperature and DO concentration in water clearly increased from the bottom to the surface layers (Figure 3). Seasonal variation in temperature and wind are the main drivers of TS. It is known to occur naturally in relatively deep-water bodies in temperate region and it's also frequently observed situation in lentic ecosystems in Turkey (Demir and Kırkağaç, 2005; Elçi, 2008, Göncü et al., 2015, Buhan et al., 2015). However, time or duration of TS formation may change in the near future (Ficker et al., 2017; O’Reilly et al., 2015; Rempfer, 2010, Magee and Wu, 2017). According to climate change predictions temperature increase and seasonal precipitation regime changes are projected all over the world (IPCC, 2013). Yozgat is in semi-arid climatic region and its characterized with hot-dry summers and cold-wet winters according to predictions dry periods during the summertime may prolong and may lead to prolonged TS conditions in aquatic water bodies. The predictions have already been observed in some studies which were conducted in aquatic ecosystems (Jankowski et al., 2006, Wilhelm and Adrian, 2007).

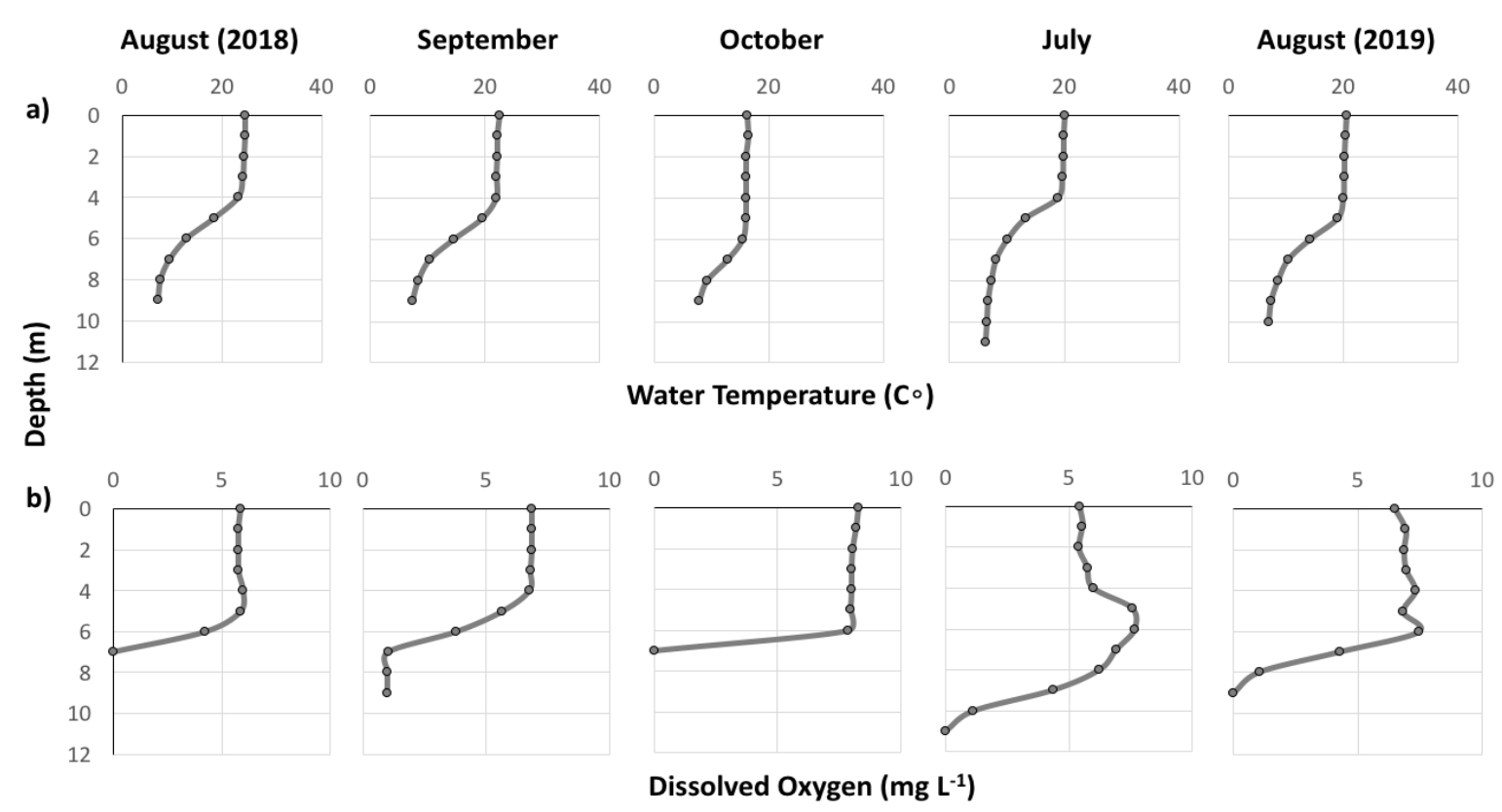

Figure 3. Depth profile of water temperature (a) and dissolved oxygen (b) during the stratified months of Cevdet Dündar Pond. 

Map and Field Measurements

Table 1. Monthly changes in the Physiological parameters of Cevdet Dündar Pond between August 2018 and August 2019

\begin{tabular}{lcccccc}
\hline \multicolumn{1}{c}{ Date } & Stratification & $\mathbf{p H}$ & $\mathbf{D O}(\mathbf{\%})$ & Conductivity $(\boldsymbol{\mu S} / \mathbf{c m})$ & Salinity $(\mathbf{p p m})$ & Total Dissolved Solid $\left(\mathbf{m g} \mathbf{L}^{-1}\right)$ \\
\hline \multirow{2}{*}{ August (2018) } & Epilimnion & $8.1 \pm 0.2$ & $81.4 \pm 1.4$ & $186 \pm 3.4$ & 0.09 & $93.2 \pm 1.7$ \\
& Hypolimnion & $7.2 \pm 0.2$ & $21.9 \pm 28.9$ & $179 \pm 10.1$ & $0.08 \pm 0.01$ & $89.8 \pm 5$ \\
\hline \multirow{2}{*}{ September } & Epilimnion & $8.1 \pm 0.1$ & $91.2 \pm 1.5$ & $177.7 \pm 0.7$ & 0.08 & $88.8 \pm 0.4$ \\
& Hypolimnion & $7.2 \pm 0.1$ & $27.5 \pm 25.1$ & $169.6 \pm 7.9$ & 0.08 & $84.9 \pm 4$ \\
\hline \multirow{2}{*}{ October } & Epilimnion & $8.1 \pm 0.3$ & $89.9 \pm 15.9$ & $182.7 \pm 1.4$ & 0.09 & $91.4 \pm 0.5$ \\
& Hypolimnion & $7.1 \pm 0.05$ & 0 & $187.6 \pm 7.5$ & 0.09 & $93.8 \pm 3.4$ \\
\hline November & No stratification & $7.8 \pm 0.3$ & $71.7 \pm 29$ & $185.9 \pm 4.6$ & 0.09 & $92.9 \pm 2.3$ \\
\hline December & No stratification & $8 \pm 0.2$ & $99 \pm 6.9$ & $182.7 \pm 5.1$ & 0.09 & $91.4 \pm 2.5$ \\
\hline April & No stratification & $7.5 \pm 0.3$ & $87.7 \pm 14.1$ & $158.7 \pm 13.1$ & 0.07 & $78.53 \pm 4.9$ \\
\hline May & No stratification & $7.7 \pm 0.1$ & $91.6 \pm 3.8$ & $159.5 \pm 2.2$ & 0.08 & $79.8 \pm 1$ \\
\hline June & No stratification & $7.7 \pm 0.1$ & $78.9 \pm 20$ & $172.6 \pm 2.5$ & 0.08 & $86.3 \pm 1.2$ \\
\hline July & No stratification & $7.7 \pm 0.2$ & $69.8 \pm 25.4$ & $177.2 \pm 5.2$ & 0.08 & $88.4 \pm 2.7$ \\
\hline \multirow{2}{*}{ August (2019) } & Epilimnion & $7.6 \pm 0.2$ & $72.9 \pm 5.3$ & $183.1 \pm 5.8$ & 0.09 & $91.4 \pm 2.8$ \\
\hline & Hypolimnion & $7.3 \pm 0.25$ & $41 \pm 33.5$ & $178.9 \pm 1.8$ & 0.08 & $89.4 \pm 3.5$
\end{tabular}

Water temperature is the one of the most important parameters in aquatic ecosystems considering the living organisms and the aquatic functioning (Wilhelm and Adrian, 2008). For instance, cyanobacteria species take advantage of prolonged TS conditions. Cyanobacteria bloom formation increase has been already observed in many aquatic ecosystems as a result of temperature increase (Pearl and Paul, 2009). In addition to their higher optimum growth temperature, buoyancy and nitrogen fixing capabilities also give advantage to them under TS conditions (Jöhnk et al., 2008; Paerl and Huisman, 2009). Since internal nutrient loading decreases from sediment to epilimnion during the TS, nutrient depletion in epilimnion may occur and lead to nutrient scarcity. In addition to the direct temperature effect, TS conditions can stimulate cyanobacterial growth, they can cope with nutrient depletion in the epilimnion via their buoyancy capability (Goldman et al., 1996; Kangro et al., 2005; Wilhelm and Adrian, 2008). On the other hand, it has been observed that duration and patterns of TS have effect on zooplankton and fish vertical distribution (Vanderploeg et al., 2009; Thackeray et al., 2005; Winder et al. 2003). Significant DO concentration difference was observed between epilimnion and hypolimnion. It is known that fish are affected by the anoxic conditions and tolerances of fish to hypoxia vary among species (Mazumder 1994, Helland et al., 2007). During the field studies, it was observed that the density of fish in the pond was high, but the species properties were not known since there is no data on fish taxonomy. Therefore, it is not possible to make detailed comments on the situation.

The bathymetric map of the pond was shown in Figure 2. The pond depth according to the bathymetric map changed between 0 and $11.1 \mathrm{~m}$ (Table 2). Depth-dependent area volume values of the pond were shown in Table 2. The maximum area and volume of the pond were calculated as 29536.7 $\mathrm{m}^{2}$ and $225209.59 \mathrm{~m}^{3}$ respectively (Table 2 ). 


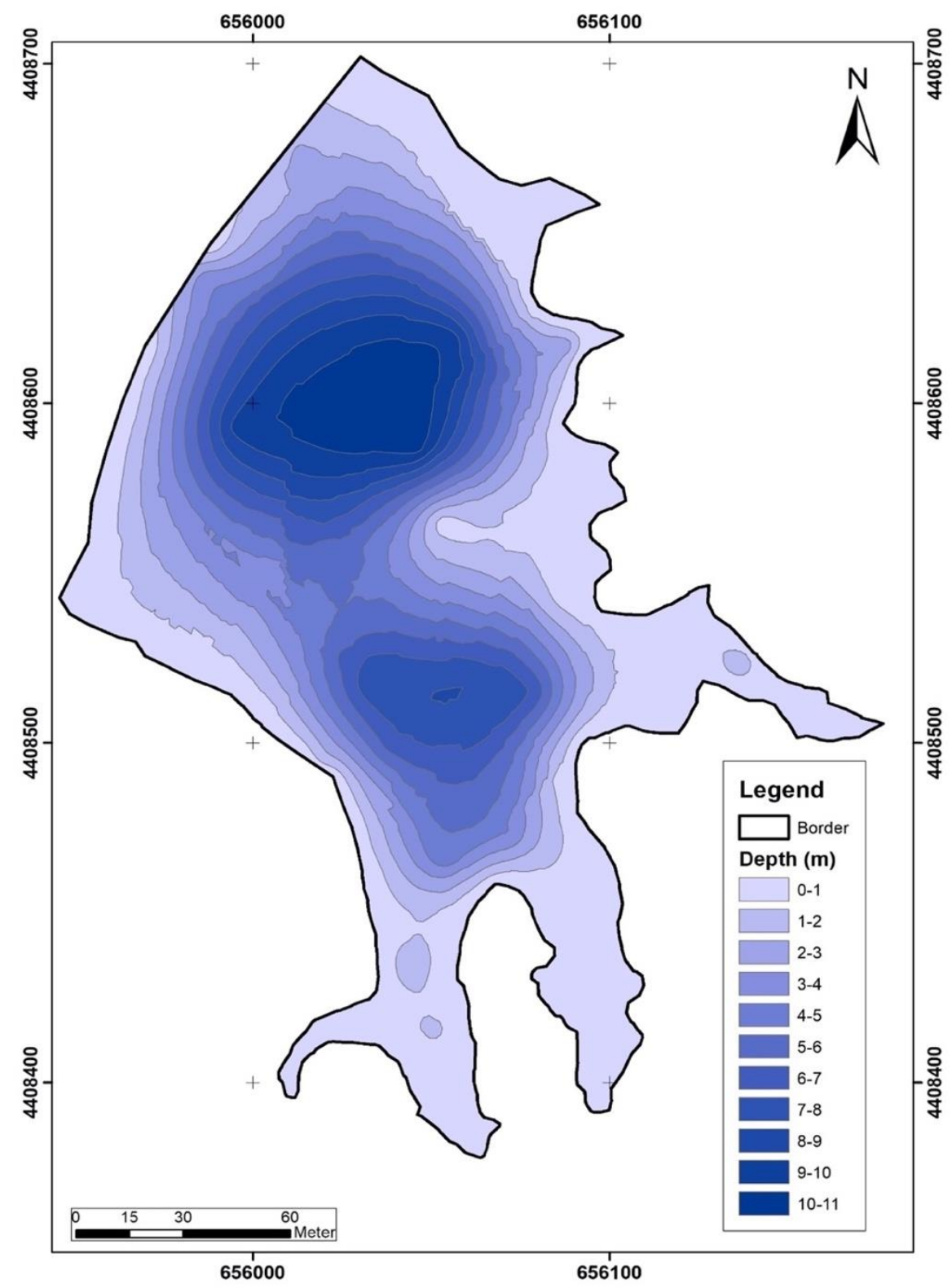

Figure 4. Batyhmetric map of Cevdet Dündar Pond

Table 2. Storage capacity of Cevdet Dündar Pond (Depth-dependent area volume values of the pond)

\begin{tabular}{lll}
\hline Depth $(\mathbf{m})$ & Area $\left(\mathbf{m}^{\mathbf{2}}\right)$ & Volume $\left(\mathbf{m}^{\mathbf{3}}\right)$ \\
\hline 0 & 210.68 & 3.24 \\
1.12 & 9920.63 & 7626.04 \\
2.23 & 13478.27 & 20811.22 \\
3.35 & 16426.91 & 37564.22 \\
4.47 & 19082.98 & 57416.92 \\
5.59 & 21839.71 & 80289.05 \\
6.7 & 23995.96 & 105930.12 \\
7.82 & 26056.68 & 133838.99 \\
8.94 & 27238.86 & 163685.86 \\
10.05 & 28438.11 & 194756.58 \\
11.1 & 29536.7 & 225209.59 \\
\hline
\end{tabular}


The pond depth changed between 9-11 m during the studying period. This means $27.3 \%$ decrease in volume and $7.8 \%$ in surface area. There is no water abstraction from the pond. Thus, these differences should be related with climatic conditions such as air temperature and evaporation. Severe droughts might cause dramatic impacts on pond volume. Even 2-fold increase in mean temperature or 2-fold decrease in precipitation might be resulted with decrease in pond volume (nearly 50\%) and surface area (nearly 19\%). Due to the climate change in the future. The pond was constructed in 1974 with 600000 $\mathrm{m}^{3}$ capacity (16 m depth). We calculated the volume as nearly $225000 \mathrm{~m}^{3}$ and measured $11 \mathrm{~m}$ depth. $65 \%$ of the pond area has become lost within 44 years. These might be related with drying or weakened inflows namely creeks of Katran, Divanlı and Kavaklı and changing climate. Yozgat province is in an area where arid terrestrial climate prevails, there is very little rainfall especially in summer. This effect is observed more clearly especially in dry years. In 2007 and 2014 in the province of Yozgat, ponds reached the drying point. Thus, the pond should be protected for the future warming climate since this pond is the only water resources for wild animals in Yozgat Pine Grove National Park and Fatih Nature Park.

\section{CONCLUSION}

Cevdet pond is an important water source for living organisms in the Yozgat Pine Grove National Park and Fatih Nature Park. For the first time bathymetric map of Cevdet Dündar Pond was created and pond volume and physicochemical parameters were measured for a year period. Hypoxic conditions and temperature decrease were observed in hypolimnion layer during the TS period. Since there is no previous study about the pond making a comparison is not possible however, temperature increase and accordingly prolonged TS periods expected according to climate change projections. Although it is advantageous to have a relatively low human impact and the status of a protected area regular monitoring studies both for pond volume and physicochemical parameters are essential. Furthermore, biological parameters like phytoplankton, zooplankton, fish and macrophyte studies has never been conducted before. To better understand pond ecosystem and to prevent the possible climate change effects on further studies would contribute greatly.

\section{ACKNOWLEDGEMENT}

This work has been supported by Yozgat Bozok University Scientific Research Projects Coordination Unit under grant number: 6602b-FEF/18-160. We are grateful to Dr. Hatice Baş and Seyfi Ali Ağtepe for their help during the field work.

\section{REFERENCES}

Akarun R, 1983. Baraj Yapımcılığında Türkiye Pratiğinin Değerlendirilmesi, s. 29-55. Devlet Su işleri Matbaas1, Ankara-Turkey.

Ayten AM, Dede OM, 2007. Milli Park Alanlarının Koruma ve Yönetim Sorunları: Yozgat Çamlık Milli Parkı Örneği, 38. Uluslararası Asya ve Kuzey Afrika Çalışmaları Kongresi 10-15 Eylül 2007, Ankara, s.165.

Brainwood M, Burgin S, 2009. Hotspots of biodiversity or homogeneous landscapes? Farm dams as biodiversity reserves in Australia. Biodiversity and Conservation, 18(11): 3043-3052.

Bucak T, Saraoğlu E, Levi EE, Tavşanoğlu ÜN, Çakiroğlu Aİ, Jeppesen E, Beklioğlu M, 2012. The influence of water level on macrophyte growth and trophic interactions in eutrophic Mediterranean shallow lakes: A mesocosm experiment with and without fish. Freshwater Biology, 57(8): 16311642. 
Buhan SD, Bektaş N, Koçer MA, Doğan HM, Buhan E, Polat F, 2015. Trophic Status and Threats In Zinav Lake (Tokat/ Turkey). Fresenius Environmental Bulletin 24(1a): 24(1a): 203-207.

Carpenter SR, Fisher SG, Grimm NB, Kitchell JF, 1992. Global Change and Freshwater Ecosystems. Annual Review of Ecology and Systematics, 23(1): 119-139.

Demir N, and Kırkağaç MU, 2005ç Plankton composition and water quality in a pond of spring origin in Turkey. Limnology, 6: 189-194.

Elçi S. 2008. Effects of Thermal Stratification and Mixing on Reservoir Water Quality. Limnology, 9(2):135-142.

Ersoy İ, Daşdemir İ, 2016. Korunan Alanlarda Yönetimin Etkinlik Düzeyinin Belirlenmesi (Soğuksu ve Yozgat Çamlığı Milli Parkları Örneği). Bartın Orman Fakültesi Dergisi, 18(1): 32-46.

Escobar J, Buck DG, Brenner M, Curtis JH, Hoyos N, 2009. Thermal stratification, mixing, and heat budgets of Florida lakes. Fundamental and Applied Limnology / Archiv Für Hydrobiologie, 174(4): 283-293.

Ficker H, Luger M, Gassner H, 2017. From dimictic to monomictic: Empirical evidence of thermal regime transitions in three deep alpine lakes in Austria induced by climate change, Freshwater Biology, 62: 1335-1345.

Goldman CR, Elser JJ, Richards RC, 1996. Thermal stratification, nutrient dynamics, and phytoplankton productivity during the onset of spring phytoplankton growth in Lake Baikal, Russia. Hydrobiologia 331: 9-24.

Göncü S, Hasanoğlu E, Avdan U, Avdan ZY, Albek EA, (2015). Borabey Göleti'ninTermal Katmanlaşma Yapısının İncelenmesi. Anadolu Üniversitesi Bilim ve Teknoloji Dergisi AUygulamalı Bilimler ve Mühendislik, 16(3): 351-366.

Harper J, 2015. Bathymetry: concepts and applications. Callisto Reference. Callisto Reference Publications, pp: 38-52 Newyork-Unites States of America.

Helland IP, Freyhof J, Kasprzak P. Mehner T, 2007. Temperature sensitivity of vertical distributions of zooplankton and planktivorous fish in a stratified lake. Oecologia, 151(2): 322-330.

Hollister J, Milstead WB, 2010. Using GIS to estimate lake volume from limited data. Lake and Reservoir Management, 26(3): 194-199.

Huertos ML, Smith D, 2013. Wetland Bathymetry and Mapping. In Wetland Techniques. Dordrecht: Springer, pp. 49-86, Netherlands.

Jankowski T, Livingstone DM, Bührer H, Forster R, Niederhauser P, 2006. Consequences of the 2003 European heat wave for lake temperature profiles, thermal stability, and hypolimnetic oxygen depletion: Implications for a warmer world. Limnology and Oceanography, 51: 815-819.

Jeppesen E, Kronvang B, Meerhoff M, Søndergaard M, Hansen KM, Andersen HE, Olesen JE, 2009. Climate Change Effects on Runoff, Catchment Phosphorus Loading and Lake Ecological State, and Potential Adaptations. Journal of Environment Quality, 38(5): 1930.

Jöhnk KD, Visser PM, Huisman J, Stroom JM, Sharples J, Sommeijer B, 2008. Summer heatwaves promote blooms of harmful cyanobacteria. Global Change Biology 14: 495-512.

Kangro K, Laugaste R, Nõges P, 2005. Long-term Changes and Seasonal Development of Phytoplankton in a Strongly Stratified, Hypertrophic Lake. Hydrobiologia 547: 91-103.

Magee MR, and $\mathrm{Wu}, \mathrm{CH}, 2017$. Response of water temperatures and stratification to changing climate in three lakes with different morphometry, Hydrology and Earth System Sciences. 21: 6253-6274. 
Mazumder A, 1994. Phosphorus-Chlorophyll Relationships under Contrasting Herbivory and Thermal Stratification: Predictions and Patterns. Canadian Journal of Fisheries and Aquatic Sciences, 51(2): 390-400.

Meerhoff M, Teixeira-de MF, Kruk C, Alonso C, González-Bergonzoni I, Pacheco JP, Jeppesen E. 2012. Environmental Warming in Shallow Lakes. A Review of Potential Changes in Community Structure as Evidenced from Space-for-Time Substitution Approaches. Advances in Ecological Research, 46: 259-349.

Moss B, 2010. Ecology of freshwaters: a view for the twenty-first century. John Wiley \& Sons.

Mutlu E, Güzel A, 2019. Evaluation of Some Physicochemical Water Quality Parameters of Gümüşsuyu Pond (Sinop-Erfelek). Turkish Journal of Agriculture - Food Science and Technology 7(3): 72-77. Mutlu E, Paruğ Ş, 2018. Dereköy Göleti'nin (Kilimli - Zonguldak) Bazı Su Kalitesi Parametrelerinin İncelenmesi. Menba Kastamonu Üniversitesi Su Ürünleri Fakültesi Dergisi, 4(2): 20-28.

O'Reilly CM, Sharma S, Gray DK, Hampton SE, Read JS, Rowley RJ et al, 2015. Rapid and highly variable warming of lake surface waters around the globe, Geophysical Research Letters 42:1077310781.

Özen A, Karapinar B, Kucuk I, Jeppesen E, Beklioglu M, 2010. Drought-induced changes in nutrient concentrations and retention in two shallow Mediterranean lakes subjected to different degrees of management. Hydrobiologia, 646(1): 61-72.

Paerl HW, and Huisman J, 2009. Climate change: a catalyst for global expansion of harmful cyanobacterial blooms. Environmental Microbiology Reports 1: 27-37.

Paerl HW, and Paul VJ, 2012. Climate change: Links to global expansion of harmful cyanobacteria, Water Research, 46(5): 1349-1363.

Rempfer J, Livingstone DM, Blodau C, Forster R, Niederhauser P, and Kipfer R, 2010. The effect of the exceptionally mild European winter of 2006-2007 on temperature and oxygen profiles in lakes in Switzerland: A fore- taste of the future? Limnology and Oceanography 55: 2170-2180.

Rowan JS, Goodwill P, Greco M, 1995. Temporal variability in catchment sediment yield determined from repeated bathymetric surveys: Abbeystead Reservoir, United Kingdom Physics and Chemistry of the Earth, 20(2): 199-206.

Şapçılar E, Fakioğlu M, 2003. Devlet Su İşleri Genel Müdürlüğü’nde Hidrografik Harita Çalışmaları. I. Ulusal Mühendislik Ölçmeleri Sempozyumu, İstanbul, s.336-355.

Schleiss AJ, Franca MJ, Juez C, De Cesare, G. 2016. Reservoir sedimentation. Journal of Hydraulic Research, 54(6): 595-614.

Takamura, N. 2012. Status of Biodiversity Loss in Lakes and Ponds in Japan. Springer pp. 133-148 Tokyo-Japan.

Tepe Y, Türkmen A, Mutlu E, Ateş A, 2005. Some Physicochemical Characteristics of Yarseli Lake, Hatay, Turkey. Turkish Journal of Fisheries and Aquatic Sciences, 5(1): 35-42.

Thackeray SJ, George DG, Jones RI, Winfield IJ, 2005. Vertical heterogeneity in zooplankton community structure: a variance partitioning approach. Archiv fur Hydrobiologie, 164: 257-275.

The Intergovernmental Panel on Climate Change, 2013. The Physical Science Basis. Working Group I Contribution to the Intergovernmental Panel on Climate Change Fifth Assessment Report, Cambridge University Press, Cambridge.

Vallee D, Jean Margat J, 2003. Review of world water sources by country. Food and Agriculture Organization of the United Nations (FAO), pp. 19, Rome-Italy. 
Vanderploeg HA, Ludsin SA, Ruberg SA, Höök TO, Pothoven SA, Brandt SB, Lang GA, Liebig JR, Cavaletto JF, 2009. Hypoxia affects spatial distributions and overlap of pelagic fish, zooplankton, and phytoplankton in Lake Erie. Journal of Experimental Marine Biology and Ecology, 381: 92107.

Vörösmarty CJ, Green P, Salisbury J, Lammers RB, 2000. Global water resources: vulnerability from climate change and population growth. Science, 289(5477): 284-288.

Wilhelm S. and Adrian R, 2007. Long-term response of Dreissena polymorpha larvae to physical and biological forcing in a shallow lake. Oecologia, 151: 104- 114.

Wilhelm S. and Adrian R, 2008. Impact of summer warming on the thermal characteristics of a polymictic lake and consequences for oxygen, nutrients and phytoplankton. Freshwater Biology, 53: 226-237.

Winder M, Buergi HR, Spaak P, 2003. Seasonal vertical distribution of phytoplankton and copepod species in a high-mountain lake. Archiv fur Hydrobiologie, 158: 197-213.

Yozgat Fatih Tabiat Parkı Gelişme Planı, planlama Raporu, 2017. T.C. Orman Ve Su İşleri Bakanlığ1 Doğa Koruma Ve Milli Parklar Genel Müdürlüğü, Yozgat-Türkiye.

Yozgat İli 2017 Yılı Çevre Durum Raporu, 2018. Yozgat Çevre ve Şehircilik İl Müdürlüğü. YozgatTürkiye.

Ziegler CK, Nisbet BS, 1995. Long-Term Simulation of Fine-Grained Sediment Transport in Large Reservoir. Journal of Hydraulic Engineering, 121(11): 773-781. 